\title{
QUALITY ASSURANCE (QA) DAN QUALITY CONTROL (QC) COBALT
}

\author{
Dita, Sofian Iramanda ${ }^{1}$, Maria Anggraini Aristianingrum ${ }^{2}$ \\ ${ }^{1}$ Departemen Fisika Fakultas Sains dan Teknologi Universitas Airlangga \\ ${ }^{2}$ Biophysics and Medical Physics Research Group, Fakultas sains dan Teknologi, Universitas \\ Airlangga \\ e-mail: ${ }^{1}$ sofian.amanda-2017@fst.unair.ac.id,${ }^{2}$ maria.anggraini.aristianingrum- \\ 2017@fst.unair.ac.id
}

\begin{abstract}
Abstrak
Cobalt-60 adalah instrumen radioterapi yang digunakan untuk mematikan sel tumor maupun kanker pada pasien. Untuk menjamin kualitas instrumen Cobalt, diperlukan QA (Quality Assurance) dan untuk membuktikan adanya jaminan kualitas perlu QC (Quality Control). Hal ini dilakukan bertujuan untuk memeriksa dan menguji data untuk menentukan standar dan mengecek kesesuaian produk mencapai operasi manufaktur yang maksimum atau ukuran yang diambil yaitu untuk menilai, merawat atau memperbaiki kualitas perlakuan yang diberikan. Program QA harus didasarkan pada penyelidikan menyeluruh untuk standar awal pada saat penerimaan dan commissioning peralatan untuk penggunaan klinis (AAPM, 1993a). International Electrotechnical Cornmission (IEC, 1989a, b), American Association of Physicists in Medicine (AAPM, 1984,1993a), dan American College of Medical Physics (ACMP, 1986) menjelaskan prosedur dan kondisi untuk tes penerimaan. Salah satu rangkaian QA QC adalah kalibrasi meliputi kalibrasi harian, mingguan, bulanan dan tahunan. Kalibrasi harian, mingguan dan bulanan dilakukan oleh fisikawan medis dengan dibantu radiografer, sedangkan kalibrasi tahunan dilakukan oleh pihak BATAN.
\end{abstract}

Kata kunci-Cobalt-60,kalibrasi, $Q A, Q C$

\begin{abstract}
Cobalt-60 is a radiotherapy instrument used to kill tumors and cancer cells in patients. To guarantee the quality of Cobalt instruments, QA (Quality Assurance) is needed and to prove the quality assurance there is a need for QC (Quality Control). This is done aiming to examine and test data to determine standards and check the suitability of the product to achieve maximum manufacturing operations or measures taken ie to assess, maintain or improve the quality of the treatment given. The QA program must be based on a thorough investigation of the initial standards at the time of receipt and commissioning of equipment for clinical use (AAPM, 1993a). The International Electro technical Cornmission (IEC, 1989a, b), the American Association of Physics in Medicine (AAPM, 1984,1993a), and the American College of Medical Physics (ACMP, 1986) describe the procedures and conditions for admission tests. One of the QA QC series is calibration which includes daily, weekly, monthly and yearly calibrations. Daily, weekly and monthly calibrations are performed by medical physicists assisted by radiographers, while annual calibrations are carried out by the BATAN.
\end{abstract}

Keywords-Cobalt-60, calibration, $Q A, Q C$

JBP Vol.23, No.02, Desember 2021-Dita, Sofian Iramanda, Maria Anggraini Aristianingrum

DOI 10.20473/jbp.v5i2.2021.61-74 


\section{PENDAHULUAN}

Pesawat teleterapi Cobalt-60 adalah instrumen radioterapi yang digunakan untuk mematikan sel tumor maupun kanker pada pasien. Untuk menjamin kualitas instrumen Cobalt, diperlukan QA (Quality Assurance) dan untuk membuktikan adanya jaminan kualitas perlu QC (Quality Control). Hal ini dilakukan juga bertujuan untuk memeriksa dan menguji data untuk menentukan standar dan mengecek kesesuaian produk mencapai operasi manufaktur yang maksimum atau ukuran yang diambil yaitu untuk menilai, merawat atau memperbaiki kualitas perlakuan yang diberikan. Peran fisikawan medis sangat penting karena hanya fisikawan medis yang menjalankan pelaksanaan jaminan kualitas instrumen radioterapi untuk memastikan bahwa semua mesin perawatan dan sumber radiasi dikalibrasi dengan benar sesuai dengan protokol yang diterima.. Setiap anggota tim QA harus mengetahui tanggung jawabnya, dilatih untuk melaksanakannya, dan tahu tindakan apa yang harus diambil jika tes atau tindakan memberikan hasil di luar batas kriteria yang dapat diterima yang ditetapkan. Catatan kualitas yang mendokumentasikan frekuensi kinerja dan hasil dari program QA adalah penting. Fisikawan harus membantu menentukan spesifikasi untuk pembelian unit perawatan, termasuk unit eksternal beam dan brachytherapy, simulator terapi, unit CT dan USG, sistem pencitraan terapi lainnya (misalnya, sistem pencitraan portal on-line ), dan sistem perencanaan perawatan. Fisikawan onkologi radiasi terlibat dalam desain fasilitas dan harus memastikan bahwa semua persyaratan keselamatan radiasi terpenuhi.

Quality Assurance (QA) atau jaminan mutu pada fasilitas radiologi adalah suatu program/langkah teratur yang bertujuan untuk menjamin konsistensi tahapan medik: pemenuhan keamanan dalam pemberian dosis untuk volume organ target tersebut dan dosis seminimal mungkin untuk jaringan normal dan papar pada personil serta pemonitoran yang cukup pada pasien setelah tindakan dengan pertimbangan biaya rendah dan dosis penyinaran terhadap pasien yang serendah rendahnya. Program QA harus didasarkan pada penyelidikan menyeluruh untuk standar awal pada saat penerimaan dan commissioning peralatan untuk penggunaan klinis (AAPM, 1993a). International Electrotechnical Cornmission (IEC, 1989a, b), American Association of Physicists in Medicine (AAPM, 1984,1993a), dan American College of Medical Physics (ACMP, 1986) menjelaskan prosedur dan kondisi untuk tes penerimaan. Prosedur ini harus diikuti untuk memverifikasi spesifikasi pabrikan dan menetapkan nilai kinerja dasar untuk peralatan baru atau yang diperbaharui, atau untuk peralatan yang mengikuti perbaikan besar. Setelah standar dasar telah ditetapkan, protokol untuk tes QA berkala harus dikembangkan untuk tujuan memantau nilai kinerja referensi. Quality Control (QC) atau kontrol mutu adalah suatu tindakan pengukuran yang rutin dilakukan untuk memonitor performa visual dan uji kinerja dari peralatan sehingga kualitas outputnya dapat dijamin. Salah satu rangkaian QA dan QC yaitu kalibrasi (calibration) atau pengukuran. Kalibrasi meliputi kalibrasi harian (daily calibration), kalibrasi mingguan (weekly calibration), dan kalibrasi bulanan (monthly calibration). Kalibrasi sangat penting dilakukan guna memastikan bahwa perangkat yang digunakan, dalam kasus ini Cobalt-60, masih sesuai standar dan tidak berbahaya bagi pasien.

\section{Radiasi}

Radiasi adalah pancaran energi dari dalam atom, radiasi dapat berupa partikel atau gelombang (BATAN,2019). Radiasi dalam bentuk partikel atau korpuskuler yaitu radiasi yang berasal dari partikel. Misalnya alfa dan beta Sedangkan radiasi dalam bentuk gelombang adalah radiasi yang tidak memiliki massa dan muatan listrik. Contohnya sinar gamma, sinar $\mathrm{X}$ dan juga cahaya tampak seperti cahaya matahari, cahaya lampu, microwave dan radio. Secara garis besar radiasi terbagi menjadi dua, diantaranya :

a. Radiasi pengion yaitu jenis radiasi yang dapat menyebabkan proses ionisasi apabila 
berinteraksi dengan materi. Jenis radiasi pengion antara lain: partikel alpha, partikel beta, sinar gamma, sinar-X dan neutron. Radiasi pengion dapat menyebabkan kematian atau kelainan pada sel, dalam waktu sementara maupun permanen. Radiasi pengion juga dapat menyebabkan mutasi pada gen, sehingga dapat mengganggu keturunan. Akan tetapi, radiasi pengion ini dapat digunakan dalam berbagai tindakan medis.

b. Radiasi non-pengion yaitu jenis radiasi yang tidak akan menyebabkan efek ionisasi apabila berinteraksi dengan materi. Jenis radiasi non-pengion antara lain: gelombang radio (yang membawa informasi dan hiburan melalui radio dan televisi), gelombang mikro (yang digunakan dalam microwave oven dan transmisi seluler handphone), sinar inframerah (yang memberikan energi dalam bentuk panas)

Sinar- $X$ dan radiasi gamma juga digunakan dalam terapi, yaitu pengobatan terhadap penyakit. Pengobatan ini didasarkan pada kemampuan radiasi yang intensif untuk membunuh sel. Sering kali, radiasi dapat mematikan tumor yang bersifat ganas. Kadangkadang radiasi digunakan untuk menggantikan pengobatan dan kadang-kadang digunakan untuk melengkapi atau menyempurnakan pengobatan. Interaksi radiasi pengion dengan materi biologi diawali dengan interaksi fisika yaitu proses ionisasi. Elektron yang dihasilkan dari proses ionisasi akan berinteraksi secara langsung maupun tidak langsung. Secara langsung bila energi elektron tersebut langsung diserap oleh molekul organik dalam sel yang secara biologik penting, seperti DNA. Secara tidak langsung bila terlebih dahulu terjadiinteraksi radiasi dengan molekul air dalam sel yang efeknya kemudian akan mengenai molekul organic yang penting. Interaksi secara fisika-kimia ini dapat menimbulkan kerusakan sel lebih lanjut yang akhirnya menimbulkan efek biologis yang dapat diamati.

Interaksi dengan sel, kerusakan terjadi pada DNA dan kromosom sel sangat bergantung pada proses perbaikan yang berlangsung. Bila proses perbaikan berlangsung dengan baik dan tepat atau sempurna, dan juga tingkat kerusakan yang dialami sel tidak terlalu parah, maka sel bisa kembali normal seperti keadaan semula. Bila proses perbaikan berlangsung namun tidak tepat maka sel tetap dapat hidup tetapi mengalami perubahan. Bila tingkat kerusakan sel sangat parah maka sel akan mati. Tingkat kerusakan sel akibat radiasi sangat bervariasi bergantung kepada tingkat sensitifitas sel terhadap radiasi. Sel yang paling sensitif adalah kulit dan sel yang mudah rusak akibat pengaruh radiasi adalah sel otak. Tumor yang ganas dikenai radiasi yang sangat kuat secara berulang-ulang, mungkin setiap hari, selama jangka waktu beberapa minggu. Radioterapi diberikan setiap hari dari berbagai arah dengan sinar radiasi yang difokuskan secara cepat agar tidak membahayakan pasien. Dengan cara ini, tumor menjadi sasaran tembakan yang bersilangan dan menerima dosis radiasi yang sangat tinggi sementara jaringan-jaringan sehat disekitarnya akan terkena radiasi dalam jumlah yang lebih sedikit. Kerusakan yang mungkin terjadi pada jaringan-jaringan sehat akan berangsur pulih pada saat pengobatan, sementara itu tumor yang ganas menjadi mati. Sehingga radiasi juga berperan penting dalam salah satu metode penyembuhan tumor atau kanker. Radiasi yang sangat intensif juga digunakan untuk sterilisasi alat-alat bedah dan obat-obat tertentu. Setiap kuman, bakteri dan mikroba mati oleh paparan radiasi yang cukup kuat dan lama. Teknik yang sama dapat diterapkan pada produk-produk makanan agar lebih tahan lama.

\subsection{Radioterapi}

Radioterapi adalah suatu jenis pengobatan yang menggunakan atau memanfaatkan radiasi pengion (sinar-X, dan sinar Gamma) dan partikel lainnya untuk mematikan sel-sel kanker tanpa akibat fatal pada jaringan sehat disekitarnya. Sehingga pelayanan radioterapi didukung oleh tim yang berpengalaman, terdiri dari: dokter spesialis Radiologi (konsultan) Onkologi Radiasi, Fisikawan medis, radiographer, radioterapi, perawat onkologi, teknisi medis, dan personil lainnya yang berhubungan dengan pelayanan radioterapi. Terapi radiasi dianggap sebagai pengobatan lokal karena hanya sel didalam dan disekitar kanker yang dituju. Hal ini tidak begitu bermanfaat melawan kanker yang sudah menyebar karena terapi radiasi umumnya tidak dibuat untuk menjangkau seluruh bagian tubuh. Radiasi berguna untuk beberapa tujuan, antara lain : 


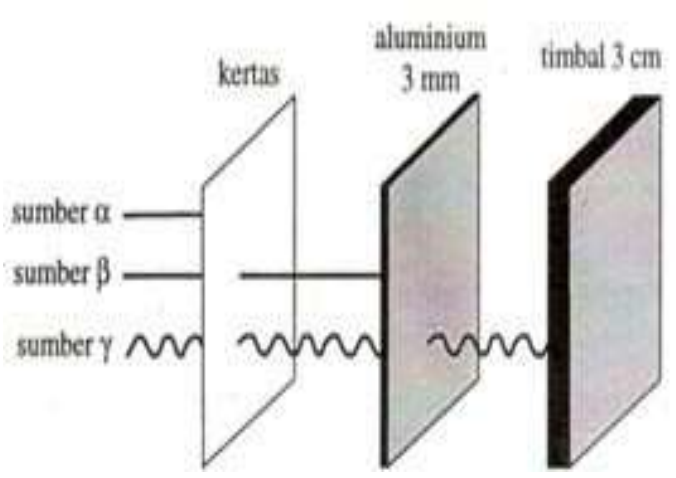

- Menyembuhkan atau mengecilkan kanker pada stadium dini. Radiasi digunakan untuk membuat kanker mengecil atau hilang sama sekali. Untuk kasus kanker lain, radiasi juga bisa digunakan untuk mengecilkan tumor sebelum operasi (pre-operative therapy) atau setelah operasi yang tujuannya untuk menjaga agar kanker tidak kambuh (adjuvant therapy). Terapi ini dapat juga dilakukan bersamaan dengan chemotherapy.

- Mencegah agar kanker tidak muncul di area lain. Apabila suatu jenis kanker diketahui menyebar ke area tertentu, kemungkinan akan dilakukan treatment untuk mencegah agar sel tersebut tidak berubah menjadi tumor. Sebagai contoh, pasien dengan beberapa tipe kanker paru-paru, mungkin akan menerima prophylactic (preventive) radiasi di kepala sebab tipe kanker ini sering menyebar ke otak.

- Mengobati gejala-gejala pada kanker stadium lanjut. Beberapa kanker mungkin telah menyebar jauh dari perkiraan pengobatan. Tetapi hal ini bukan berarti kanker tersebut tidak bisa diobati agar pasien merasa lebih baik. Radiasi bisa untuk membebaskan dari rasa sakit, masalah pada pemasukkan makanan, bernafas atau pada usus besar, yang semua itu disebabkan oleh kanker yang sudah pada stadium lanjut. Cara ini biasa dinamakan palliative radiation.

Sinar gamma adalah radiasi gelombang elektromagnetik yang terpancar dari inti atom dengan energi yang sangat tinggi yang tidak memiliki massa maupun muatan. Sinar gamma memiliki beberapa sifat alamiah berikut ini:

1. Sinar gamma tidak memiliki jangkauan maksimal di udara, semakin jauh dari sumber maka intensitasnya semakin kecil.

2. Mempunyai daya ionisasi paling lemah.

3. Mempunyai daya tembus yang terbesar.

Gambar 1. Daya tembus partikel alfa, beta dan gamma

Prinsip radioterapi adalah memberikan dosis radiasi yang mematikan tumor pada daerah yang telah ditentukan (volume target) sedangkan jaringan normal sekitarnya mendapat dosis seminimal mungkin. Hal ini sangat ditunjang dengan kemajuan teknologi dari alat-alat radioterapi dan kemajuan dari komputer. Perkembangan teknologi di dunia kedokteran tidak dapat dipungkiri telah membantu penderita penyakit untuk sembuh dari sakit yang dideritanya dan meningkatkan kualitas hidup penderita tersebut. Teknik radiasi dilakukan dengan dua cara yaitu secara eksternal dan internal (brakhiterapi). Radiasi eksternal / teleteraphy adalah bentuk pengobatan radiasi dengan sumber radiasi mempunyai jarak dengan target yang dituju atau berada diluar tubuh. Terdapat dua pesawat yang digunakan untuk terapi eksternal ini, yakni pesawat Cobalt-60 yang sumbernya disimpan dalam container metal yang tebal dan pesawat Linear Accelerator (LINAC). Pada mesin LINAC menggunakan gelombang elektromagnetik frekuensi tinggi untuk mengakselerasi elektron menjadi energi tinggi melalui tabung vakum linear. Sumber yang dipakai adalah sinar $\mathrm{X}$ atau photon yang merupakan pancaran gelombang elektromagnetik yang dikeluarkan oleh pesawat linear accelerator (LINAC), sedangkan sumber untuk pesawat Co-60 adalah radioaktif Cobalt-60. Prinsip penggunaan kedua pesawat ini hampir sama yakni target berada pada jarak tertentu dari source. Secara umum jika menggunakan pesawat Cobalt-60 jarak source ke target adalah $80 \mathrm{~cm}$, sedangkan jika menggunakan pesawat LINAC jarak source ke target adalah $100 \mathrm{~cm}$. Alasan mendasar mengenai jarak antara source ke target baik 
menggunakan pesawat Cobalt-60 maupun menggunakan pesawat LINAC adalah karena pergerakan fokus sumber, efisiensi (jika terlalu jauh atau melebihi yang telah ditentukan maka energi yang terpancar sampai mencapai target akan membutuhkan energi yang lebih besar dan waktu yang lama) dan karena elektron kontaminasi yang berada di sekitar $50 \mathrm{~cm}$ dari source.

Pada terapi internal ialah dengan brakhiterapi. Brakhiterapi adalah penggunaan dari isotop radioaktif Iridium192 untuk pengobatan, dengan menempatkan bahan radioaktif ke dalam atau berdekatan dengan sasaran radiasi. Hal ini bertujuan agar diperoleh distribusi dosis radiasi yang tinggi dan homogen dalam ruang lingkup yang sesuai dengan bentuk dan volume sasaran radiasi, sedang dosis pada jaringan sehat disekitarnya rendah, sehingga dapat dicapai kontrol lokal yang tinggi dengan efek samping yang rendah. Treatment dengan menggunakan brachytherapy lebih sulit daripada rencana terapi sinar eksternal, khususnya dalam brachytherapy interstitial, dan pada tingkat yang lebih rendah dalam terapi intracavitary, intraluminal, dan plak.

Pesawat cobalt memiliki kekurangan radioterapi dengan pesawat teleterapi cobalt dibanding dengan pesawat LINAC. Kelebihan dari pesawat teleterapi cobalt adalah:

1. Memerlukan tenaga listrik yang rendah karena pesawat teleterapi cobalt ii menggunakan sumber radioaktif, sehingga memerlukan tenaga listrik yang lebih rendah jika dibandingkan dengan pesawat teleterapi LINAC

2. Biaya operasional yang relatif murah

Kekurangan dari pesawat teleterapi cobalt adalah:

1. Pemakaian Co-60 memberikan limbah radioaktif. Limbah radioaktif memerlukan penanganan khusus agar tidak mencemari lingkungan sekitar dan tidak membahayakan penduduk.

2. Permukaan tubuh mendapatkan dosis yang jauh lebih tinggi daripada kanker yang berada dalam tubuh, sehingga hasilnya tidak begitu maksimal Pada pembahasan ini, difokuskan mengenai radioterapi dan khusunya dengan menggunakan pesawat terapi Cobalt-60.

\subsection{Pesawat Cobalt-60}

Pesawat Co-60 menggunakan sumber radiasi bahan radioaktif Cobalt 60 yang menghasilkan sinar gamma. Sinar Gamma adalah istilah untuk radiasi elektromagnetik energi tinggi yang diproduksi oleh transisi energi karena percepatan elektron. diketahui bahwa daya penetrasi sinar- $\mathrm{X}$ dalam jaringan amat tergantung dari energi yang dihasilkan oleh tabung. Makin tinggi perbedaan tegangan antara katoda dan anoda, makin besar pula daya tembus sinar. Berarti untuk tumor-tumor yang letaknya dalam diperlukan pesawat-pesawat dengan tegangan yang tinggi. Gamma bermuatan 0 (nol) dihasilkan akibat transisi inti nukleon. Sumber (head source) Co-60 berada pada gantry yang dapat diatur penyudutannya dari 0 - 360. Pada saat ini Co-60 yang mempunyai energi ekuivalen dengan sinar- $\mathrm{X}$ $3 \mathrm{mV}$, digunakan baik sebagai radiasi eksternal (teletherapy) maupun radiasi internal (brachytherapy, yaitu implantasi

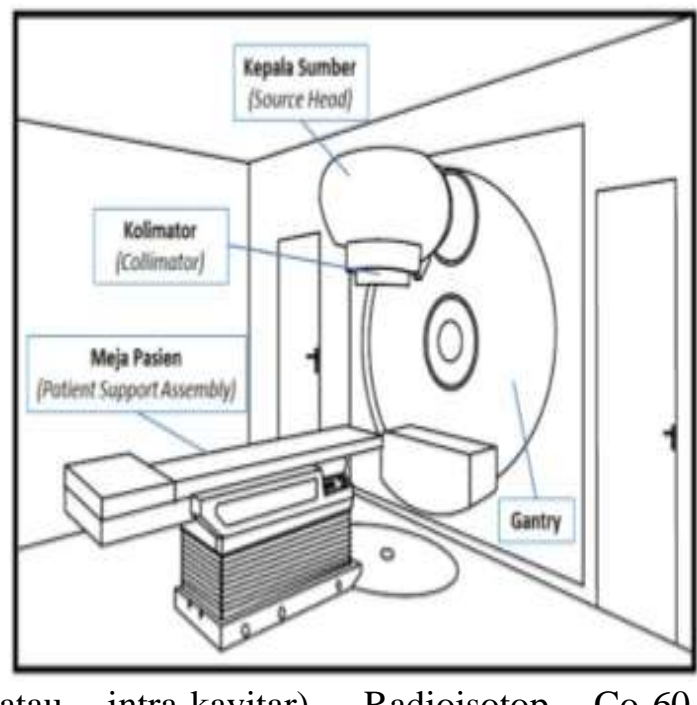

atau intra-kavitar). Radioisotop Co-60 memiliki waktu paruh sebesar 5,2710 tahun.

Gambar 2. Sketsa umum perangkat radioterapi eksternal menggunakan Cobalt-60

Sinar gamma memiliki daya tembus yang tinggi dibandingkan partikel alpha maupun 
beta. Bahan untuk menahan sinar gamma biasanya diilustrasikan dengan ketebalan yang dibutuhkan untuk mengurangi intensitas dari sinar gamma. Pesawat Co-60 memiliki lampu kolimator dan fiber optik yang berfungsi untuk mendapatkan titik sentral dari luas lapangan penyinaran, mengatur jarak sumber ke obyek dengan mengubah ketinggian meja.

Gambar 2 merupakan sketsa umum perangkat radioterapi eksternal menggunakan Cobalt-60.

Pesawat teleterapi Cobalt-60 perlu dikalibrasi setiap hari, minggu, bulan dan tahun. Penyimpangan output radiasi pesawat teleterapi Cobalt-60 terjadi karena geometri dari isotop berbentuk silinder bukan bola dan berkas radiasi yang digunakan ialah berkas terkolimasi. Keberhasilan pelaksanaan teleterapi dengan menggunakan pesawat teleterapi Cobalt-60 sangat dipengaruhi oleh faktor ukuran dan geometris sumber, serta jarak sumber kepermukaan kulit pasien. Untuk mengetahui pengaruh faktor-faktor tersebut terhadap karakteristik radiasi pesawat telecobalt-60, maka telah dilakukan simulasi dengan menggunakan model sumber berbentuk piringan, model sumber berbentuk titik, dan menggunakan model persamaan empiris.

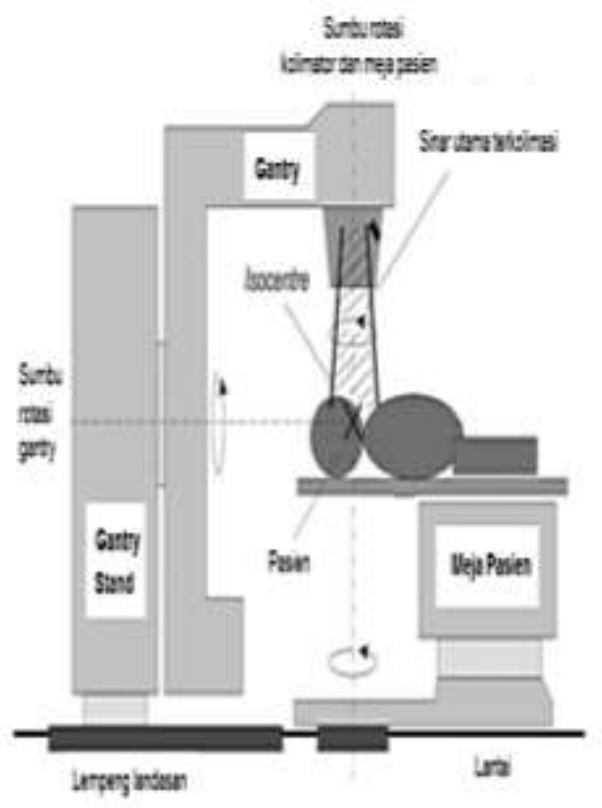

Gambar 3. Cara kerja perangkat radioterapi eksternal menggunakan Cobalt60 .

Dari hasil simulasi, secara umum diperoleh bahwa semakin kecil diameter sumber, maka profil dosis keluaran pesawat akan semakin flatness, yang berarti sebaran dosis pada daerah teradiasinya akan semakin seragam. Semakin jauh sumber radiasi dari bidang pengamatan (SSD semakin besar) maka sebaran dosis pada bidang pengamatan tersebut akan semakin seragam. Untuk SSD konstan, semakin dalam titik pengamatan berada dalam phantom maka sebaran dosisnya akan semakin seragam. Gambar 3. merupakan cara kerja perangkat radioterapi eksternal Cobalt-60 yang digunakan untuk meradiasi pasien.

\subsection{Jaminan Kualitas pada Radioterapi}

Jaminan kualitas pada radioterapi adalah semua prosedur yang dapat menjamin konsistensi tahapan medik, yaitu : pemenuhan keamanan dalam pemberian dosis untuk volume organ target tersebut, dan dosis seminimal mungkin untuk jaringan normal dan paparan pada personil serta pemonitoran yang cukup pada pasien setelah tindakan. Untuk membuktikan adanya jaminan kualitas perlu penilaian kualitas (quality assessment) dan kontrol kualitas (quality control). Penilaian kualitas adalah kegiatan yang dilaksanakan untuk mengukur atau mengevaluasi kinerja proses radioterapi. Sedangkan kontrol kualitas adalah ukuran yang diambil untuk menilai, merawat atau memperbaiki kualitas perlakuan. Dari kuesioner yang diberikan WHO kepada 56 institusi dari 52 negara didapat jawaban bahwa Program Jaminan Kualitas pada radioterapi perlu dilakukan untuk:

1. Meminimalkan kesalahan dalam perencanaan perlakuan dan pemberian dosis pada pasien serta memperbaiki hasil terapi dan mengurangi komplikasi serta kekambuhan 
2. Sebagai ajang interkompararasi radioterapi, baik nasional, regional dan internasional

3. Mengeksploitasi kinerja peralatan radioterapi modern. Hal ini dapat tercapai bila derajat akurasi tinggi dan konsistensi tercapai.

4. Meningkatkan aplikasi radioterapi di negara berkembang.

Desain perangkat radioterapi eksternal menggunakan Cobalt-60 ini mengutamakan keselamatan bagi pasien, operator, tenaga medis, dan lingkungan sekitar perangkat radioterapi eksternal. Desain perangkat radioterapi eksternal menggunakan Cobalt60 ini mengacu pada peraturan dan standar teknis yang berlaku. Pedoman, peraturan, dan standar yang digunakan adalah sebagai berikut:

- IAEA Safety Series No.115, International Basic Safety Standards for Protection against Inonizing Radiation and for the Safety of Radiation Sources, 1996.

- IAEA Safety Report Series No.38, Aplying Radiation Safety Standards in Radiotherapy, 2006.

- IAEA Safety Report Series No.47, Radiation Protection in the Design of Radiotherapy Facilities, 2006.

- IAEA Safety Report Series No.398, Absorbed Dose Determination in External Beam Radiotherapy - An International Code of Practice for Dosimetry Based on Standards of Absorbed Dose to Water, 2000.

- IAEA TECDOC No.1040, Design and implementation of a radiotherapy programme: Clinical, medical physics, radiation protection and safety aspect, 2006.

- IEC 60601-1-1. Medical electrical equipment- Part1-1: General requirements for safety- Collateral standard: Safety standard: Safety requirements for medical electrical systems, 2000.

- Peraturan Kepala BAPETEN.

Sebagai persyaratan untuk jaminan mutu dan kendali kualitas (QA/QC), peralatan Radioterapi dalam pengobatan kanker, maka dilengkapi peralatan dosimeter:

1. Dosimeter invivo

2. Dosimeter absolute maupun relative

Sedangkan untuk keamanan atau keselamatan petugas juga dilengkappi dengan

\section{Thermoluminescene dosimeter(TLD) \\ 2. Pocket dosimeter}

\section{METODE PENELITIAN}

Metode penelitian yang digunakan yaitu dengan menganalisa hasil QA dan QC pada Rumah Sakit Umum Daerah Dr. Soetomo Surabaya dengan standar referensi internasional untuk pengoperasian alat Cobalt-60. Program QA harus didasarkan pada penyelidikan menyeluruh untuk standar awal pada saat penerimaan dan commissioning peralatan untuk penggunaan klinis (AAPM, 1993a). International Electrotechnical Cornmission (IEC, 1989a, b), American Association of Physicists in Medicine (AAPM, 1984,1993a), dan American College of Medical Physics (ACMP, 1986) menjelaskan prosedur dan kondisi untuk tes penerimaan. Salah satu rangkaian QA dan $\mathrm{QC}$ adalah kalibrasi meliputi kalibrasi harian, mingguan, bulanan dan tahunan. Prosedur kalibrasi pada RSUD Dr. Soetomo ini yang akan dianalisa dan dipelajari dengan kesesuaian pedoman standar yang digunakan secara umum.

\section{HASIL DAN PEMBAHASAN}

Quality Assurance (QA) atau jaminan mutu pada fasilitas radiologi adalah suatu program/langkah teratur yang bertujuan untuk menjamin konsistensi tahapan medik: 
pemenuhan keamanan dalam pemberian dosis untuk volume organ target tersebut dan dosis seminimal mungkin untuk jaringan normal dan pada personil serta pemonitoran yang cukup pada pasien setelah tindakan dengan pertimbangan biaya rendah dan dosis penyinaran terhadap pasien yang serendah rendahnya Program QA harus didasarkan pada penyelidikan menyeluruh untuk standar

\begin{tabular}{|c|c|c|}
\hline \multirow{3}{*}{$\begin{array}{l}\text { Frequency } \\
\text { Daily }\end{array}$} & Procedure & Tolerance \\
\hline & \begin{tabular}{|l|} 
Safety \\
-Door interlock \\
- Radiation room \\
$\quad$ monitor \\
$\circ \quad$ Audiovisu \\
al \\
$\quad$ monitor
\end{tabular} & $\begin{array}{l}\text { Functional } \\
\text { Functional } \\
\text { Functional }\end{array}$ \\
\hline & \begin{tabular}{|l}
\multicolumn{2}{|l|}{ Mechanical } \\
-Lasers \\
$\quad \begin{array}{l}\text { Distance } \\
\text { indicator } \\
\text { (ODI) }\end{array}$
\end{tabular} & $\begin{array}{l}1 \mathrm{~mm} \\
2 \mathrm{~mm}\end{array}$ \\
\hline
\end{tabular}

commissioning peralatan untuk penggunaan klinis.

Quality Control $(Q C)$ atau kontrol mutu adalah suatu tindakan pengukuran yang rutin dilakukan untuk memonitor performa visual dan uji kinerja dari peralatan sehingga kualitas outputnya dapat dijamin.

Jaminan kualitas pada radioterapi adalah semua prosedur yang dapat menjamin konsistensi tahapan medik, yaitu : pemenuhan keamanan dalam pemberian dosis untuk volume organ target tersebut, dan dosis seminimal mungkin untuk jaringan normal dan paparan pada personil serta pemonitoran yang cukup pada pasien setelah tindakan.

Penilaian kualitas adalah kegiatan yang dilaksanakan untuk mengukur atau mengevaluasi kinerja proses radioterapi, sedangkan kontrol kualitas adalah ukuran yang diambil untuk menilai, merawat atau memperbaiki kualitas perlakuan.

\subsection{DAILY TEST PADA PESAWAT COBALT-60 SHINVA FCC8000F}

Jaminan kualitas harian di Instalasi Radioterapi RSUD Dr. Soetomo dilakukan pada semua alat terapi karena harus dalam keadaaan yang layak sebelum dilakukan terapi pada pasien, suatu alat. Pengecekan setiap hari pada cobalt-60 ini dilakukan karena adanya ketidakstabilan berkas terhadap waktu. Hal ini sangat penting dilakukan mengingat ketepatan dan ketelitian dosis yang diberikan pada pasien sangat mempengaruhi efektivitas pengobatan atau perlakuan terapi. Pada ruangan cobalt dilengkapi pula dengan kunci manual dimana kunci tersebut akan diletakkan pada kotak kunci yang yang memiliki sandi sehingga hanya operator dan yang bersangkutan yang dapat membuka ruangan cobalt tersebut sehingga pada ruang radioterapi cobalt ini sering disebut memiliki keamanan berganda.

\section{Tabel 1. Daily test pada Cobalt-60}

Pada Tabel 1. menunjukkan beberapa komponen pada pesawat teleterapi cobalt-60 yang harus dilakukan tes setiap hari untuk mengetahui jaminan kualitas harian. Seperti alarm pada ruangan, speaker dan alat-alat pemantau lainnya yang dapat memantau dan memandu pasien dari ruang operator.

Dari Tabel 1. dapat dijelaskan bahwa unutk pengecekan setiap harinya pintu harus berfungsi sebagaimana mestinya, ruang monitor radiasi serta monitor audiovisual harus juga berfungsi dengan baik hal ini dikarenakan agar keamanan pasien dan orang disekitar ruangan radiasi tetap terjaga keamananya dari bahaya radiasi. Untuk laser terdapat 3 laser di ruang cobalt Instalasi Radioterapi RSUD Dr.Soetomo. Laser ini berfungsi untuk menentukan titik isocenter pada pasien dan kedalaman tumor/kanker pada tubuh pasien yang disesuaikan dengan data Treatment Planning System dan simulator dan untuk mengecek fungsi laser dan ODI yaitu dengan meletakkan kertas millimeter blok pada couch, usahakan agar kertas tidak bergeser bisa dengan cara diplester pada ujung-ujung kertas. Lalu membuat titik-titik pada kertas millimeter sebagai acuan posisi center lalu memposisikan laser ketinggian pada permukaan kertas millimeter lalu

68

JBP Vol.23, No.02, Desember 2021-Dita, Sofian Iramanda, Maria Anggraini Aristianingrum

DOI 10.20473/jbp.v5i2.2021.61-74 
menghidupkan lampu ODI dan memeriksa indicator ODI (menunjukkan angka berapa) dan mencatat pada quality routine check paper jika menunjukkan angka $100 \mathrm{~cm}$ maka beri tanda cek pada kolom routine check paper, selanjutnya memposisikan crosswire(field) pada titik-titik kertas millimeter, lalu memeriksa laser longitudinal dan sagital dan mencatat pergeseran pada kertas quality routine check paper indicator jarak parameternya yaitu jika terjadi melebihi $2 \mathrm{~mm}$ akan dilakukan tindakan. Table ini didiapatkan dari publikasi American Institute of Physics. Ruangan radioterapi cobalt juga harus memiliki CCTV. CCTV ini digunakan saat sedang dilakukan radiasi sebagai pemantau pasien, karena pada saat dilakukan terapi, tidak ada seorangpun yang boleh masuk ruang cobalt 60 maka, semua arahan untuk pasien akan disampaikan lewat speaker atau pengeras suara. Jika pasien bergerak saat dilakukan radiasi, maka teknisi atau petugas akan memberhentikan proses radiasi dan melanjutkan kembali setelah pasien kembali ke posisi semula. Kamera CCTV ini terhubung pada ruang operator cobalt-60 sehingga petugas atau operator dalam memantau keadaan pasien tanpa harus masuk kedalam ruangan radiasi cobalt-60.

\begin{tabular}{|l|l|}
\hline No & Item yang diuji \\
\hline 1 & Posisi sumber \\
\hline
\end{tabular}

Semua komponen diatur di komputer operator. Peran fisika medis dalam hal ini yaitu menentukan mutu jaminan alat. Mutu jaminan diatas merupakan yaitu mutu jaminan harian (daily test) yang harus selalu dicek setiap hari setiap akan melakukan terapi. Pengecekan komponen diatas perlu untuk dilakukan untuk mengetahui kelayakan alat cobalt. Jika alat pesawat terapi cobalt tersebut tidak memenuhi atau sesuai dengan standar maka dapat membahayakan bagi pasien, para pekerja dan lingkungan sekitarnya. Jika kesalahan tersebut terjadi, maka petugas fisika medis harus memberitahukan kepada teknisi alat pesawat cobalt agar dilakukan perbaikan.

\subsection{WEAKLY TEST PADA PESAWAT COBALT-60 SHINVA FCC8000F}

Quality assurance external beam radiation theraphy cobalt terdapat pengecualian yaitu terdapat test atau pengecekan mingguan. Hal ini berbeda dengan quality assurance pada pesawat radiasi lainnya seperti contoh ialah LINAC perbedaan ini dikarenakan cobalt memakai bahan radioaktif yang memancarkan sinar gamma untuk terapi penyembuhannya berbeda dengan pesawat teleterapi LINAC pada LINAC tidak menggunakan bahan radioaktif seperti pada pesawat teleterapi cobalt dan sinar yang dipancarkan pada LINAC berupa sinar-X, sehingga pada peswaat teleterapi LINAC tidak memerlukan pengecekan atau kalibrasi setiiap minggunya berbeda dengan pesawat teleterapi Cobalt pada pesawat teleterapi Cobalt ini memerlukan pengecekan mingguan untuk mengetahui atau melihat posisi dari sumber radioaktif tersebut. pengecekan berkala (mingguan) ini untuk melihat apakah sumber radioaktif masih dalam posisi yang tepat, untuk mengetahui pula apakah sumber radioaktifnya masih ada atau sudah habis. Jika posisi sumber bergeser maka pesawat teleterapi ini todak dapat digunakan untuk terapi karena dapat membahayakan pasien.

Tabel 2. Weakly test pada Cobalt-60

Tabel 2. menunjukkan komponen pada pesawat teleterapi cobalt-60 yang harus dilakukan tes setiap minggu.

\subsection{MONTHLY TEST PADA PESAWAT COBALT-60 SHINVA FCC8000F}

Kontrol kualitas bulanan biasanya dilakukan pada parameter-parameter yang mengalami perubahan-perubahan secara minor (kecil), karena kemungkinan perubahan parameter-parameter tersebut sangat kecil dalam waktu satu bulan. Kontrol kualitas bulanan ditujukan untuk parameter parameter yang mempunyai dampak kecil terhadap pasien, sebagai contoh: indikator jarak meja pasien (baik pada posisi lateral, 
longitudinal, pengaturan ketinggian ataupun rotasi), luas lapangan cahaya penyinaran, dan lain-lain. Perhitungan dosis mengacu pada Technical Report Series 398 (TRS-398). Penggunaan acuan kalibrasi Technical Report Series 398 (TRS-398) berlaku untuk pesawat teleterapi linear accelerator dan cobalt pada RSUD Dr Soetomo Surabaya. Monthly test ini salah satunya yaitu kalibrasi dengan menggunakan air disebut juga water phantom.

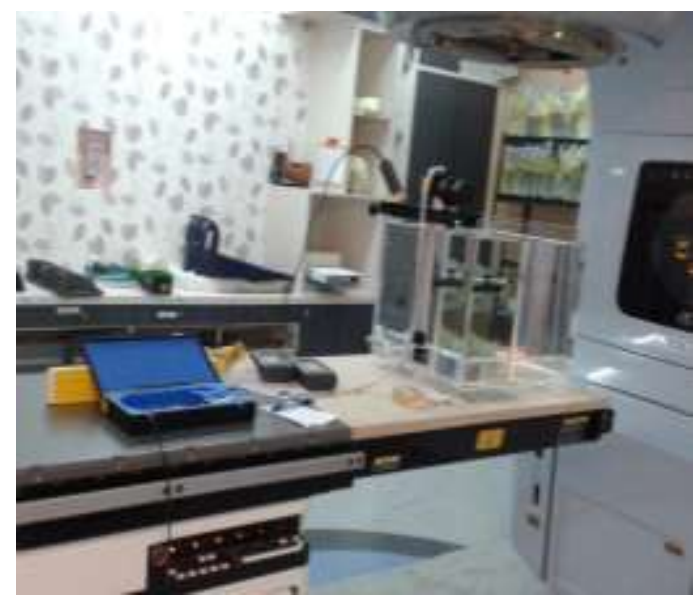

Gambar 5.16 Set alat water phantom

Perangkat water phantom digunakan sebagai kalibrator unutk mengatur ulang fungsi alat scan seperti semula sehingga menjadi di bawah batas toleransi. Seperangkat alat water phantom akan mendeteksi berupa keluaran dosis yang ditampilkan melalui elektrometer dengan satuan MU (Monitor Unit), sehingga kalibrasi alat pesawat cobalt menggunakan Water Phantom seperti pada Gambar 4. sangat penting dilakukan agar tidak terjadi kesalahan pada tampilan dosis keluaran. Secara umum, Tabel 3. merupakan tabel dari control kualitas bulanan pada pesawat cobalt.

Tabel 3. Monthly test pada Cobalt-60 berdasarkan AAPM

\begin{tabular}{|l|l|l|}
\hline Frequency & Procedure & Tolerance \\
\hline Monthly & Dosimetry & \\
& $\bullet$ Output & $2 \%$ \\
\hline
\end{tabular}

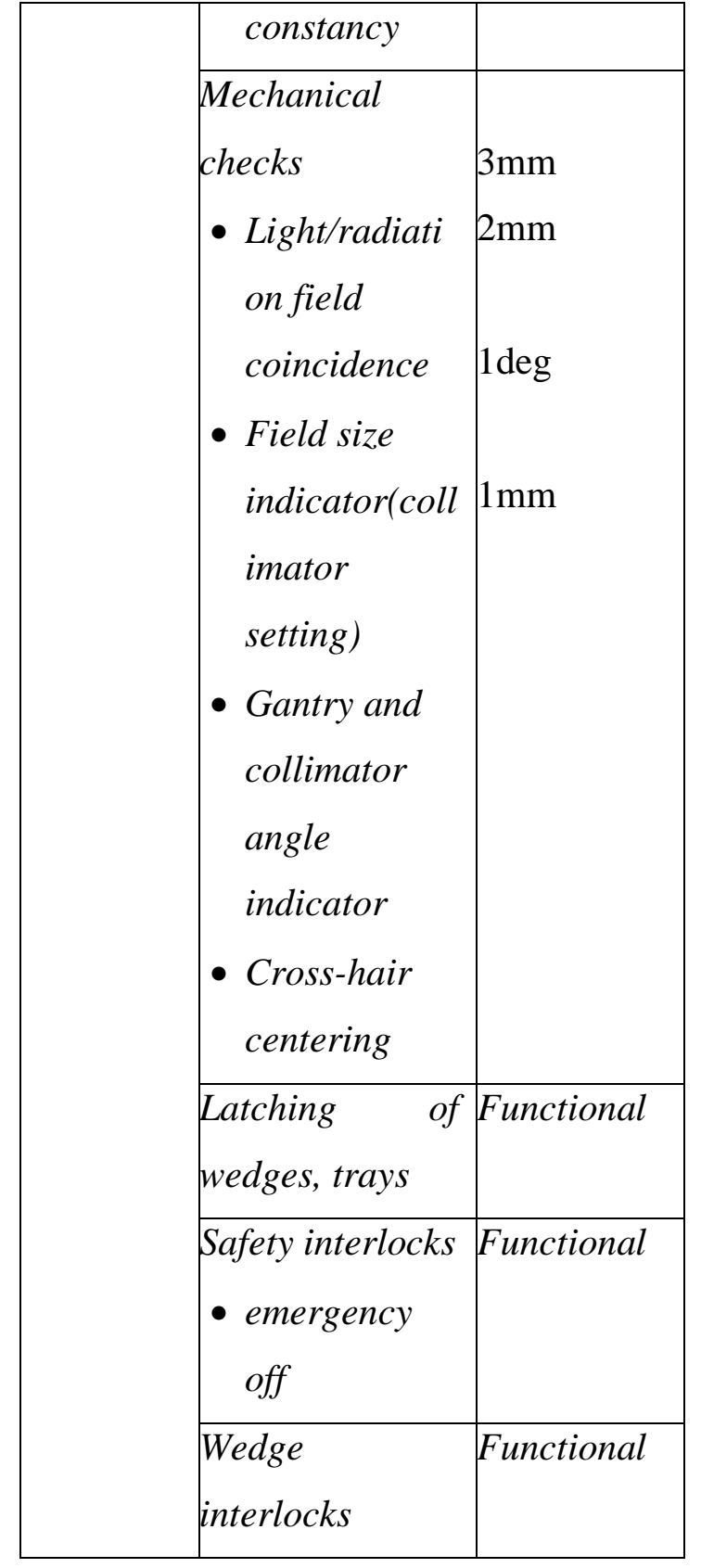

Dijelaskan bahwa pada Tabel 3. kolom Tolerance, disini dapat diisi dengan parameter dan akan dilakukan tindakan apabila kurang sesuai parameternya. Untuk frekuensi bulanan pada RSUD Dr. Soetomo parameter yang dicek ialah mengenai toleransi/keadaan aksesoris visual, tombol emergency, rotasi gantry dengan toleransi 0.5 . Pengecekan dilakukan pula pada peralatan pembatasan sumbu berkas, isosenter, pointer depan dan belakang,

JBP Vol.23, No.02, Desember 2021-Dita, Sofian Iramanda, Maria Anggraini Aristianingrum

DOI 10.20473/jbp.v5i2.2021.61-74 
peralatan pembatasan simetri/parallel yang masing-masing memiliki toleransi $2 \mathrm{~mm}$.
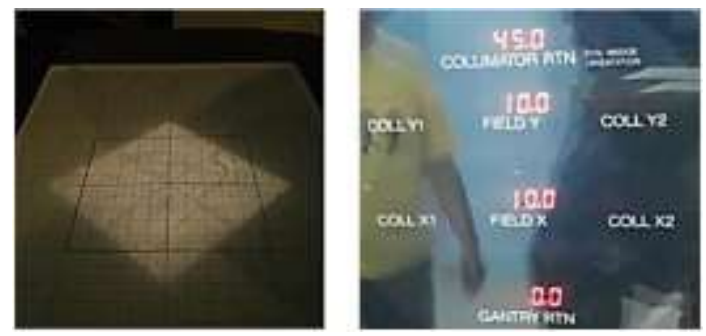

Gambar 5. Perputaran Sudut Kolimator

Gambar di atas merupakan posisi kolimator pada sudut 45 derajat. Dari gambar tersebut menunjukan bahwa sudut 45 yang diatur sesuai dengan sudut kolimator yang menuju target (pasien). Gambar tersebut juga menunjukan bahwa perubahan sudut pada kolimator tidak mempengaruhi posisi isocenter.

Tabel 3. ini berdasarkan publikasi dari American Institute of Physics dan menjadi referensi RSUD dr Soetomo Surabaya untuk mengkalibrasi pesawat cobalt.

\subsection{ANNUAL TEST PADA PESAWAT COBALT-60 SHINVA FCC8000F}

Jaminan kualitas tahunan perlu dilakukan setiap tahun. Salah satu parameter yang perlu diperiksa yaitu keluaran dosis pesawat cobalt. Dosis keluaran pesawat cobalt yang telah diukur dengan menggunakan Water Phantom setiap bulan akan dilihat stabilitasnya. Jika stabilitas terjaga dengan baik, maka alat pesawat cobalt masih bekerja dengan baik. Pada kalibrasi tahunan petugas kalibrasi dari Badan Tenaga Nuklir Nasional (BATAN). Ketika petugas mendapati adanya ketidaksesuaian pada alat radioterapi maka alat tersebut akan dinonaktifkan atau tidak dignakan hingga alat tersebut selesai diperbaiki oleh teknisi ahli. Setelah diperbaiki oleh teknsi seorang fisikawan medis tetap harus memastikan alat tersebut dapat berfungsi dengan baik untuk terapi radiasi. Apabila masih diketahui keluaran dosis Pesawat cobalt tidak lagi stabil, maka seorang fisikawan medis harus melaporkan kesalahan tersebut kepada seorang teknisi alat
Pesawat cobalt sehingga dapat diperbaiki dan dapat bekerja dengan baik.

Tabel 4. Annual test pada Cobalt-60 berdasarkan AAPM

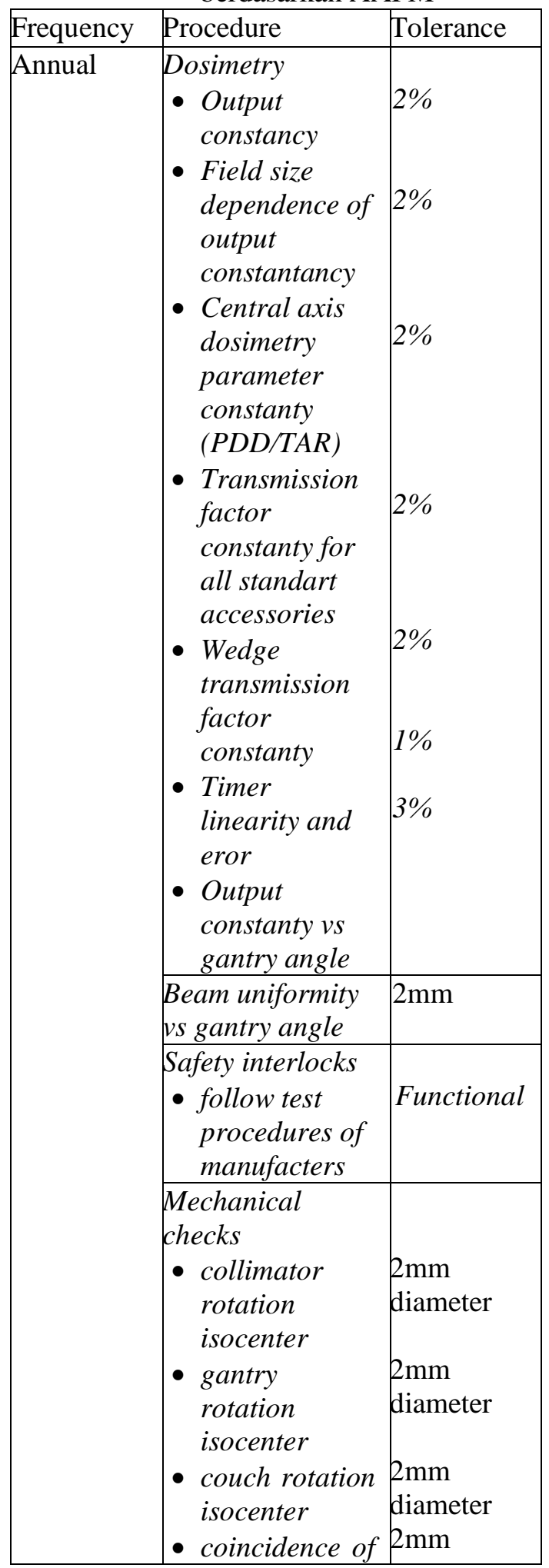

JBP Vol.23, No.02, Desember 2021-Dita, Sofian Iramanda, Maria Anggraini Aristianingrum

DOI 10.20473/jbp.v5i2.2021.61-74 
medis dan instansi yang berwenang. Dalam menjalankan kalibrasi fisikawan medis dapat juga dibantu oleh radiographer. Kalibrasi alat dilakukan oleh fisikawan medis RSUD Dr. Soetomo Surabaya ialah pada pagi hari sebelum alat radioterapi digunakan. Pembagian jadwal kalibrasi alat radioterapi ditentukan dari masing-masing instansi rumah sakit. Namun untuk kalibrasi tahunan petugas kalibrasi adalah dari Badan Tenaga Nuklir Nasional. Setelah melakukan kalibrasi seorang fisikawan medis harus menuliskannya pada quality routine check paper dari masing-masing alat radioterapi yang dikalibrasi dan selanjutnya disimpan sebagai arsip rumah sakit

Tabel 5. Jadwal kalibrasi pada Cobalt-60

\begin{tabular}{|l|l|}
\hline KALIBRASI & PETUGAS \\
\hline HARIAN & Fisikawan Medis \\
\hline MINGGUAN & Fisikawan Medis \\
\hline BULANAN & $\begin{array}{l}\text { Fisikawan Medis dan } \\
\text { Radiografer }\end{array}$ \\
\hline TAHUNAN & BATAN \\
\hline
\end{tabular}

Pada Tabel 5. menunjukkan jadwal kalibrasi pada cobalt-60 di RSUD Dr soetomo Surabaya.

\section{KESIMPULAN}

Pesawat teleterapi Cobalt-60 merupakan salah satu alat terapi dengan radiasi menggunakan radioisotop Cobalt-60 yang memancarkan sinar gamma. Sumber radiasi sering mengalami pergerakan, maka perlu dilakukan pengecekan secara berkala agar kestabilan output radiasi tetap terjaga dan sebagai salah satu fungsi kendali mutu dan jaminan kualitas. Salah satu rangkaian QA QC adalah kalibrasi meliputi kalibrasi harian, mingguan dan bulanan. RSUD Dr. Soetomo Surabaya memiliki 1 pesawat cobalt, yang berjenis COBALT-60 SHINVA FCC8000F/C246, dengan spesifikasi sebagai berikut :

Kalibrasi untuk mesin radioterapi Cobalt60 dilakukan oleh tenaga ahli yaitu fisikawan 


\section{SARAN}

Mahasiswa yang akan melakukan Praktik Kerja Lapangan (PKL) di Instalasi Radioterapi RSUD Dr. Soetomo Surabaya untuk selanjutnya diharapkan mempelajari terlebih dahulu materi dasar tentang radioterapi dan mempersiapkan bahan berupa pertanyaan untuk memudahkan dalam penyusunan laporan serta mempelajari anatomi tubuh manusia agar mempermudah komunikasi dalam penyampaian materi dalam dunia medis.

\section{UCAPAN TERIMA KASIH}

Kegiatan dan laporan PKL ini dapat diselesaikan dengan baik karena penulis mendapatkan banyak bantuan dan dukungan dari berbagai pihak baik berupa informasi, arahan dan bimbingan oleh karena itu penulis mengucapkan terima kasih kepada :

1. Dr. Suryani Dyah Astuti selaku dosen pembimbing yang telah banyak memberikan ilmu dan dukungan kepada kami.

2. dr. Dyah Erawati, Sp.Rad (K) Onk.Rad selaku Kepala Instalasi Radioterapi yang telah mengizinkan kami untuk melaksanakan Praktek Kerja Lapangan di Instalasi Radioterapi RSUD Dr. Soetomo Surabaya.

3. Bapak Bambang Haris Suhartono, S.Si. M.Si selaku dosen pembimbing lapangan yang telah mengarahkan kami dalam pelaksanaan Praktek Kerja Lapangan di Instalasi Radioterapi RSUD Dr. Soetomo Surabaya.

1. M. Rizqi Aditya Rahman, S.Si yang telah membimbing kami dalam pelaksanaan Praktek Kerja Lapangan.

2. Wulandhari, S.Si yang juga telah membimbing kami dalam pelaksanaan Praktek Kerja Lapangan.
3. Bu Anis selaku radiografer yang telah mengajarkan pada kami bagaimana pengoperasian alat dalam treatment pada Brakhiterapi.

4. Pak Ahdy Rozidy, Amd.SE selaku Kepala Tata Usaha di Instalasi Radioterapi RSUD Dr. Soetomo Surabaya yang telah membantu kami di bidang administrasi.

5. Bagian Pusdiklat RSUD Dr. Soetomo Surabaya yang telah menerima proposal awal sehingga kami dapat melaksanakan Praktek Kerja Lapangan.

\section{DAFTAR PUSTAKA}

Akhadi, Mukhlis. 2000. Dasar-Dasar Proteksi Radiasi. Jakarta: Rineka

Cipta.

Amalia T dan Kurniawan B. 2004. "Analisa Profil Berkas Elektron Pesawat

Akselerator Linear Medik." dalam Jurnal Departemen Fisika MIPA.

Jakarta : Universitas Indonesia

Anies. 2006. "Potensi Gangguan Kesehatan Akibat Radiasi Elektromagnetik

SUTET”. Jakarta : Kelompok Gramedia.

Arismunandar dan Silakhuddin. 2000. "Struktur dan Segi-segi Keselamatan Linac Medik" dalam Pusat Pengembangan Sistem ReaktorMaju. BATAN. ISSN:0854-2910.

Asrisal R, Dewang S dan Tahir D. 2013. "Verivikasi Berkas Elektron Pesawat Linear Acceleration (LINAC) dengan Variasi Energi pada Water Phantom". Jurusan Fisika Fakultas MIPA : Universitas Hasanuddin.

Chember H. 1983. Pengantar Fisika Kesehatan (Terjemahan Achmad Toekiman) edisi kedua. Semarang : IKIP

Dharmawati dan Suharni. 2012. "Implementasi Linear Accelaration dalam penanganan kasus kanker" dalam Prosiding PPI Teknologi Akselator dan Aplikasinya Volume 14 (hlm. 36-47). 
Jurnal Biosains Pascasarjana Vol. 23 (2021) pp

(C) (2021) Sekolah Pascasarjana Universitas Airlangga, Indonesia

Khan, Faiz M. 1994. The Physics of Radiation Therapy. 2th Edition. Williams \& Wilkins : Sydney.

Khan, Faiz M. 1994. The Physics of Radiation Therapy. 3th Edition. Williams \& Wilkins : Sydney

Metcalfe P, Kron T dan Hoban.P. 2007. "The Physics of Radioteraphy X- ray and Electron" dalam Medical Physics Publishing. Madison : Wisconsin

Podgorsak, E.B. 2005. "Radiation Oncology Physics". Austria : IAEA

Peraturan Kepala Badan Pengawas Tenaga Nuklir Nomor 3 Tahun 2013 tentang
Keselamatan Radiasi dalam Penggunaaan Radioterapi . BATAN.

Suhartono, Z. 1990. Dosimetri Radiotherapy. Jakarta: PSPKRBATAN.

Warjono, Sulistyo dan Endang Triyani. 2011. Pesawat Radioterapi Pada Rumah Sakit 